\title{
Soybean Peptide: Novel Plant Growth Promoting Peptide from Soybean
}

\author{
Yoshiki Matsumiya and Motoki Kubo \\ Department of Biotechnology, College of Life Sciences \\ Ritsumeikan University, Nojihigashi, Kusatsu, Shiga \\ Japan
}

\section{Introduction}

Soybean is one of the most important agricultural products and its global production was more than 200 million tons per year in 2005 (Table 1) (Ministry of Agriculture, Forestry and Fisheries (Japan), 2007; Uchida, 2007). Soybean is used mainly as a vegetable oil (31.6 million tons a year in 2005) and the production ratio is the highest (30\%) among vegetable oils.

Soybean waste, which remains after extraction of vegetable oil, contains about $50 \%$ proteins, which consist of a well-balanced mix of amino acids. Therefore, soybean waste is a valuable biomass for animal feedstuffs. Soybean is used directly as food in Japan and several Asian countries but soybean proteins are used less widely elsewhere in the world.

\begin{tabular}{cc}
\hline $\begin{array}{c}\text { Agricultural } \\
\text { products }\end{array}$ & $\begin{array}{c}\text { Production } \\
\text { (Million tons) }\end{array}$ \\
\hline Corn & 710 \\
Wheat & 624 \\
Rice & 401 \\
Soybean & 214 \\
Barley & 153 \\
\hline
\end{tabular}

Table 1. Amount of main agricultural production in 2005. (Ministry of Agriculture, Forestry and Fisheries (Japan), 2007)

Recently, investigations into utilization of proteins from soybean waste have been carried out for the development of high quality foods. Protein fractions, such as soy protein isolates (SPI) and whey protein are industrially produced, and these fractions are used as additives for the improvement of food nutrition (Malhotra \& Coupland, 2004). Several soybean proteins have been purified and utilized as medicines for hypotension, rheumatism, and cholesterol control. Peptide inhibiting angiotensin I converting enzyme has also been developed by a protease treatment (Farzamirad \& Aluko, 2008; Yonekura \& Tanaka, 2003; Yonekura et al., 2004).

On the other hand, soybean waste was the most utilized $N$ source for organic fertilizers prior to the 1940s (Okuda, 1961). Recently, utilization of organic fertilizers for the production of organic agricultural products is rising because healthcare and environmental concerns are increasing. Studies into utilization of soybean waste as a fertilizer and as 
bioactive materials have been attempted (Kubo et al., 1997; Matsumiya et al., 2007; Shinano et al., 1991; Yamazaki \& Roppongi, 1998).

This chapter describes utilization of soybean meal and the development of a bioactive peptide for plant growth. Moreover, mechanisms of novel bioactive peptides for root hair promotion are described in this chapter.

\section{Isolation of soybean meal degrading bacteria and analysis of effectiveness of the degraded products as fertilizers}

Because of increasing environmental concerns, the excessive utilization of chemical fertilizers has recently received increased attention. Therefore, the development of new fertilizers using natural materials, such as amino acids and natural nitrogen compounds, has become the focus of much research (Acea et al., 1988; Klopper et al. 1989; O'Sullivan et al., 1991).

Soybean meal, which is produced in large amounts as biomass, is rich in nitrogen compounds and has been utilized as fertilizer. Degradation and mineralization of soybean meal in the soil environment requires several reactions: proteins $\rightarrow$ peptides \& amino acids $\rightarrow$ ammonia $\rightarrow$ nitrite $\rightarrow$ nitrate (Smith et al., 1977). The proteins $\rightarrow$ peptides \& amino acids reaction is important for nitrogen mineralization in the soil environment (Kamimura \& Hayano, 2000; Watanabe \& Hayano, 1995). However, the degradation of soybean meal in the soil is too slow for mineralization.

Isolation of Bacillus circulans HA12, which degrades soybean meal efficiently and rapidly, is described here (Hasegawa et al., 2002; Kubo et al., 1994), and the plant growth promoting effects of the degraded soybean meal products (DSP) are also described in this section.

\subsection{Isolation of soybean meal degrading bacteria}

Soybean meal degrading bacteria were isolated using a $1 \%(\mathrm{w} / \mathrm{v})$ soybean meal medium (Kubo et al., 1994), and about 50,000 bacteria were isolated. Protease production of all isolates were tested by LC agar medium (Matsumiya et al., 2004), resulting in 21 strains being isolated. Each isolate was further sub-cultured in soybean meal medium at $50^{\circ} \mathrm{C}$ for 48 h. As a result, the protease-producing bacterium HA12 was isolated. The procedure for the screening is shown in Fig. 1.

Strain HA12 was characterized and identified based on Bergey's Manual of Determinative Bacteriology (Buchanan \& Gibbons, 1974). Because the strain was strictly aerobic, gram positive, catalase producing, and endospore forming, the strain belongs to genus Bacillus. The maximum temperature for the growth of strain HA12 was $55^{\circ} \mathrm{C}$. The characteristics of the strain are listed in Table 2. Strain HA12 is identified as B. circulans and designated as B. circulans HA12.

\subsection{Analysis of soybean meal degradation by B. circulans HA12}

$B$. circulans HA12 formed a clear halo on LC agar medium and the strain degraded soybean meal efficiently. The protease activity was $550 \mathrm{U} / \mathrm{ml}$ after $16 \mathrm{~h}$ of cultivation (Kubo et al., 1997). The protease(s) from B. circulans HA12 was secreted into the medium and the optimum temperature of the protease was about $70^{\circ} \mathrm{C}$.

Strain HA12 consumed dissolved soybean proteins for primary metabolism during the first stage. During the next stage, soybean meal was degraded and protein accumulated gradually in the medium. Subsequently, proteins were further digested to smaller molecules, including peptides and amino acids. The maximum concentrations of peptides 
produced by degradation of soybean meal with B. circulans HA12 for $48 \mathrm{~h}$ were $6.5 \mathrm{mg} / \mathrm{ml}$ ( $1 \% \mathrm{w} / \mathrm{v}$ soybean meal medium) and $30 \mathrm{mg} / \mathrm{ml}(10 \% \mathrm{w} / \mathrm{v}$ soybean meal medium). The amino acid composition of DSP is shown in Table 3.

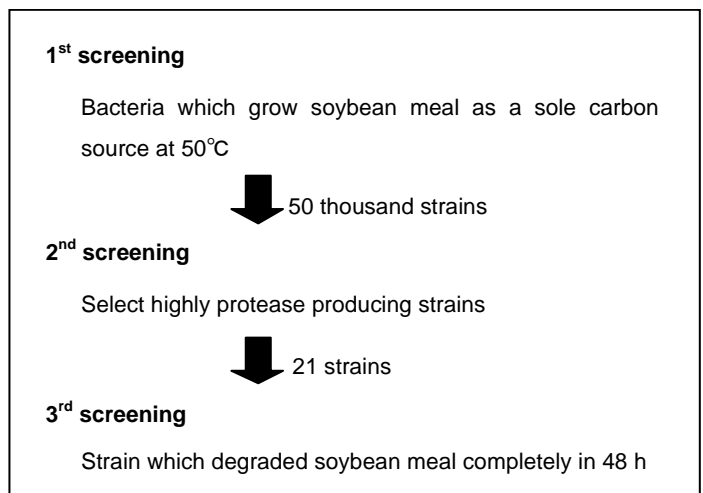

Fig. 1. Screening procedure for soybean waste-degrading bacteria.

\begin{tabular}{|c|c|c|c|}
\hline Property & Growth & Property & Growth \\
\hline Cell morphology & Rod & Growth in urease & + \\
\hline Gram staining & + & Growth in $\mathrm{NaCl} 0 \%$ & + \\
\hline Spore formation & + & $3 \%$ & + \\
\hline Motility & - & $7 \%$ & - \\
\hline Growth at: $25^{\circ} \mathrm{C}$ & + & Hemolysis & - \\
\hline $37^{\circ} \mathrm{C}$ & + & Decarboxylation from ornithine & - \\
\hline Strict aerobic reaction & + & Decarboxylation from lysine & - \\
\hline Oxidase reaction & + & Decarboxylation from arginine & + \\
\hline Catalase reaction & + & Gas from glucose & + \\
\hline Nitrate reduction & - & Gas from mannitol & + \\
\hline $\mathrm{H}_{2} \mathrm{~S}$ production & - & Gas from lactose & + \\
\hline Indole production & + & Gas from sucrose & + \\
\hline Methyl red reaction & + & Gas from maltose & + \\
\hline
\end{tabular}

Table 2. Properties of strain HA12.

\begin{tabular}{cccccc}
\hline Amino acid & $\begin{array}{c}\text { Mol. } \\
(\%)\end{array}$ & Amino acid & $\begin{array}{c}\text { Mol. } \\
(\%)\end{array}$ & Amino acid & $\begin{array}{c}\text { Mol } \\
(\%)\end{array}$ \\
\hline Ala & 5.84 & His & 1.37 & Pro & 6.74 \\
Arg & 3.35 & Ile & 4.75 & Ser & 4.27 \\
Asp & 13.33 & Leu & 6.29 & Thr & 3.32 \\
Cys & 0.00 & Lys & 7.66 & Trp & 0.00 \\
Glu & 18.40 & Met & 1.86 & Tyr & 4.64 \\
Gly & 6.61 & Phe & 6.25 & Val & 5.31 \\
\hline
\end{tabular}

Table 3. Amino acid composition of degraded soybean meal products. 


\subsection{Effect of degraded soybean meal products on plant growth}

Because DSP includes small molecules such as peptides, the plant growth promoting effects of DSP were investigated. The fresh weight of Brassica rapa was increased by $25 \%$ through addition of DSP (12 mg-peptides/kg-soil) (Table 4 \& Fig. 2). The growth of Solanum tuberosum L., Solanum lycopersicum, and Brassica juncea were also promoted by addition of DSP. Moreover, DSP produced thicker roots than a chemical fertilizer (Fig. 3).

The total nitrogen, total phosphate (TP), and total potassium (TK) in DSP were $0.70,0.11$, and $0.28 \%$, respectively. These TP and TK contents are not enough to act as a fertilizer in DSP, and moreover, DSP did not contain nitrate. Therefore, the plant growth promotion of DSP appears to be caused by bioactive peptides.

\begin{tabular}{lcc}
\hline & $\begin{array}{c}\text { Fresh weight } \\
(\mathrm{g})\end{array}$ & $\begin{array}{c}\text { Relative yield } \\
(\%)\end{array}$ \\
\hline Water & $44.2 \pm 5.2$ & 100 \\
Chemical fertilizer & $53.3 \pm 6.6$ & 121 \\
DSP & $55.1 \pm 6.9$ & 125 \\
\hline
\end{tabular}

Table 4. Effect of degraded soybean meal products on growth of Brassica rapa.

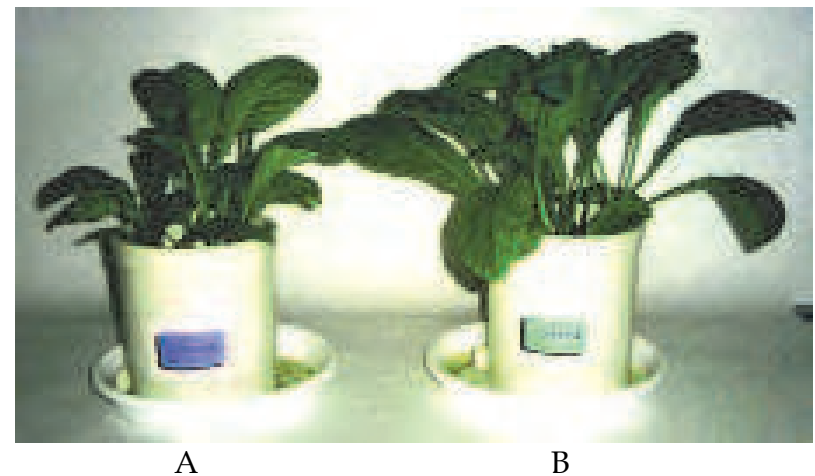

Fig. 2. Plant growth-promoting effect of degraded soybean meal products (DSP). A: Brassica rapa grown with chemical fertilizer, B: B. rapa grown with DSP.

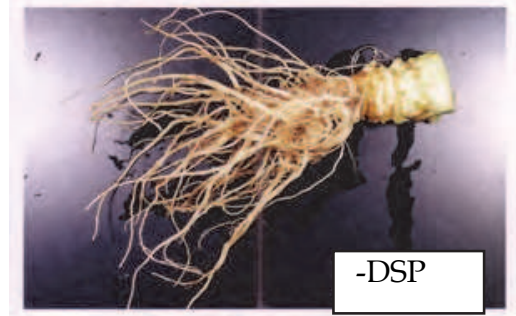

A

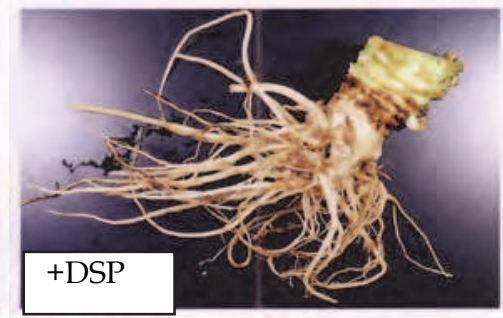

B

Fig. 3. Effect of degraded soybean meal products (DSP) on the root system of Brassica juncea. A: root of B. juncea grown in soil without DSP, B: B. juncea grown in soil with DSP. 


\subsection{Effect of DSP on root hair promotion}

Recently, several bioactive peptides from plants have also been found to have phytohormone-like activities (Ito et al., 2006; Kondo et al., 2006; Matsubayashi and Sakagami, 1996; Matsubayashi et al., 1999; McGurl et al., 1992; Pearce et al., 1991; Schopfer et al., 1999; Suzuki et al., 1999). Phytosulfokine, systemin, SCR/SP11, and CLE are endogenous peptides produced in a variety of plants. The respective bioactivities of these peptides cause cell differentiation, protease inhibitor induction, cell division, and the pollen selfincompatibility response.

In order to analyze the plant growth promoting effect, the effect of DSP on root of B. rapa was analyzed. The number of root hairs was increased and elongated when DSP $(30 \mu \mathrm{g} / \mathrm{ml})$ was added (Fig. 4). DSP also promoted the root hair formation of B. oleracea L., Lactuca sativa, Trifolium incarnatum L., and Gypsophila elegans.

Root hair is an important plant organ for the absorption and transport of nutrients (Gilroy \& Jones, 2000; Lauter et al., 1996). The enhancement of plant growth by DSP is caused by the increase of root hair numbers and length. Root hair promotion is observed with even 0.3 $\mu \mathrm{g} / \mathrm{ml}$ of DSP, and the root hair promoting activity increases with DSP concentration.

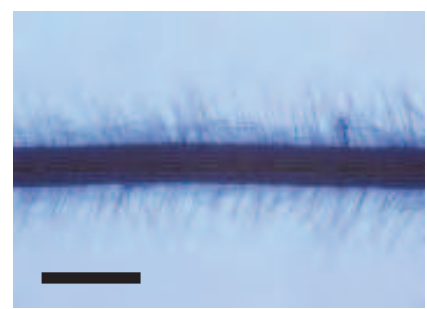

A

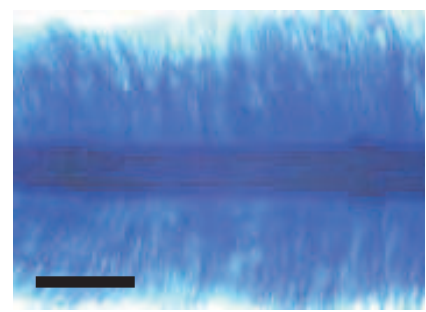

B

Fig. 4. Root hair promoting effect of degraded soybean meal products (DSP). A: root of Brassica rapa grown in plant growth medium (Matsumiya et al., 2007), B: root of B. rapa grown with DSP in plant growth medium. Bar denotes $1 \mathrm{~mm}$.

\subsection{Comparison between bioactive effects of DSP and phytohormones}

Ethylene, which is a phytohormone, also promotes root hair numbers and length. The bioactive effects of DSP and ethylene were compared (Fig. 5). The root hair promotion by DSP was similar to ethylene, but spiraling of the main root was observed in the case of ethylene.

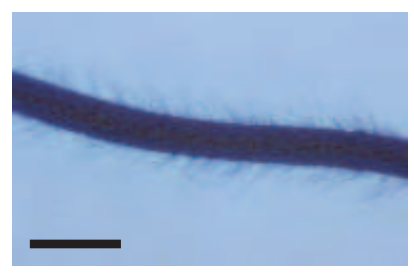

A

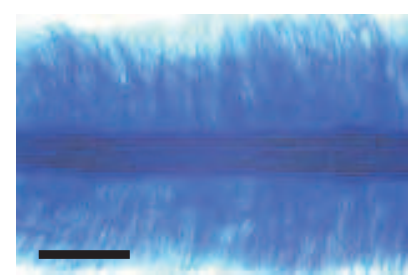

B

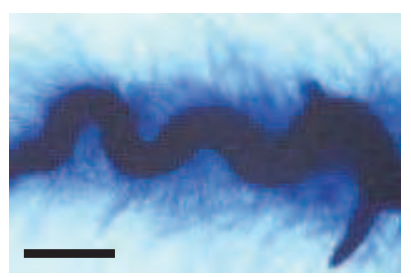

C

Fig. 5. Effects for main root and root hairs of degraded soybean meal products (DSP) and ethylene against Brassica rapa. A: plant growth medium, B: plant growth medium + DSP, C: plant growth medium + ethylene. The bar shows $1 \mathrm{~mm}$. 
On the other hand, adventitious root formation by DSP and ethylene were analyzed (Fig. 6). Obvious adventitious root formation was observed in the case of DSP addition. DSP and ethylene showed different effects on main root and adventitious root formation, suggesting that DSP did not induce ethylene for root hair promotion.

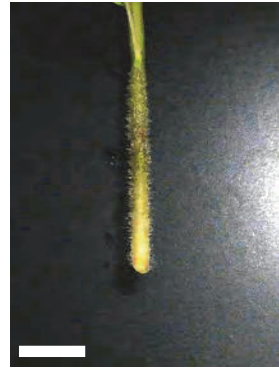

A

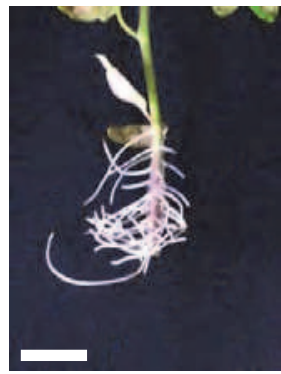

B

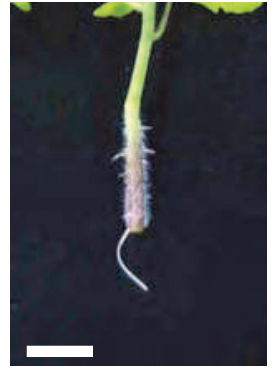

C

Fig. 6. Adventitious root formation with degraded soybean meal products (DSP) or phytohormones in Lycopersicon esculentum. The adventitious root formation assays were carried out using shoots of L. esculentum soaked in DSP and ethylene for 1 week at $25^{\circ} \mathrm{C}$. A: water, B: water + DSP, C: water + ethylene. The bar denotes $2 \mathrm{~cm}$.

\begin{tabular}{lccccccc}
\hline & $\begin{array}{c}\text { Root } \\
\text { hair }\end{array}$ & $\begin{array}{c}\text { Adventitious } \\
\text { root }\end{array}$ & $\begin{array}{c}\text { Shoot } \\
\text { growth }\end{array}$ & Epinasty & Diapause & $\begin{array}{c}\text { Callus } \\
\text { induction }\end{array}$ & $\begin{array}{c}\text { Leaf } \\
\text { enlargement }\end{array}$ \\
\hline Ethylene & + & + & - & + & - & - & - \\
Auxin & - & + & - & - & - & + & - \\
Cytokinine & - & - & - & - & - & - & + \\
Gibberelin & - & - & + & - & - & - & - \\
Abscisic acid & - & - & - & - & + & - & - \\
Brassinosteroid & - & - & + & - & - & - & - \\
Jasmoic acid & - & - & - & - & - & - & - \\
DSP & + & ++ & - & - & - & - & - \\
\hline
\end{tabular}

Table 5. Bioactive effects of degraded soybean meal products or phytohormones on plants.

The bioactive effects of DSP and phytohormones on plants were analyzed (Table 5) (Gaither, 1975; Masucci \& Schiefelbein, 1994; Pitts et al., 1998; Tanimoto et al., 1995;). The effects of DSP on plants did not agree with those of phytohormones, and therefore DSP has different mechanisms of action on plant growth.

\section{Exogenous bioactive peptides in DSP and the structural determination of the root hair promoting peptide}

Systemin (McGurl et al., 1992; Pearce et al., 1991), phytosulfokine (Matsubayashi and Sakagami, 1996; Matsubayashi et al., 1999), SCR/SP11 (Schopfer et al., 1999; Suzuki et al., 1999), and CLV3 (Ito et al., 2006; Kondo et al., 2006) have been identified as endogenous peptide signals, which act as phytohormones. On the other hand, 2,3-butandiol, which is produced by several Bacillus strains, is known as an exogenous signal for plants (Ryu et al., 
2003). DSP seems to comprise an exogenous peptide signal and shows bioactivity for root hair promotion similar to that of phytohormones. In this section, the effect of DSP on roots and the structure of the root hair promoting peptide in DSP are described.

\subsection{Effect of DSP on roots}

To analyze the mechanism by which root hair numbers and length are increased by DSP, the number of trichoblasts (hair cells) and atrichoblasts (hairless cells) were counted. The trichoblast number in the presence of DSP $(30 \mu \mathrm{g} / \mathrm{ml})$ increased about 4.4 times over that without DSP, and the atrichoblast number also increased in response to DSP treatment by about 1.9 times (Table 6). The effect of DSP on the root hair seems to be similar to that of ethylene (phytohormone) (Dolan, 1996; Masucci, \& Schiefelbein, 1994; Tanimoto et al., 1995;).

Ethylene led to an increase in root hair numbers by converting atrichoblasts to trichoblasts, while the localization pattern of the trichoblasts and atrichoblasts was not altered by addition of DSP (Fig. 7). DSP did not affect the balance of the endogenous phytohormones. DSP contains exogenous peptide signal(s) for root hair promotion and causes root hair promotion through a different mechanism than that of ethylene.

\begin{tabular}{|c|c|c|c|c|c|}
\hline Treatment & $\begin{array}{c}\text { Trichoblast } \\
\text { number } \\
\text { (cells } / \mathrm{mm}^{2} \text { ) } \\
(\%)\end{array}$ & $\begin{array}{c}\text { Atrichoblast } \\
\text { number } \\
\text { (cells } / \mathrm{mm}^{2} \text { ) } \\
(\%)\end{array}$ & $\begin{array}{l}\text { Length of } \\
\text { root hair } \\
(\mathrm{mm}) \\
(\%)\end{array}$ & $\begin{array}{c}\text { Thickness of } \\
\text { root hair }(\mu \mathrm{m}) \\
(\%)\end{array}$ & $\begin{array}{c}\text { Surface area of } \\
\text { root hair } \\
\left(\mathrm{mm}^{2} / \mathrm{mm}^{2}\right) \\
(\%)\end{array}$ \\
\hline - DSP & $\begin{array}{c}51.5 \\
(100) \\
\end{array}$ & $\begin{array}{c}66.7 \\
(100) \\
\end{array}$ & $\begin{array}{c}0.34 \\
(100)\end{array}$ & $\begin{array}{l}9.39 \\
(100) \\
\end{array}$ & $\begin{array}{c}0.26 \\
(100) \\
\end{array}$ \\
\hline + DSP & $\begin{array}{l}224.2 \\
(435)\end{array}$ & $\begin{array}{l}124.2 \\
(186)\end{array}$ & $\begin{array}{c}0.99 \\
(290)\end{array}$ & $\begin{array}{l}12.4 \\
(132)\end{array}$ & $\begin{array}{c}4.32 \\
(1,660)\end{array}$ \\
\hline
\end{tabular}

Table 6. Effects of degraded soybean meal products on root hair size and density in Brassica rapa.

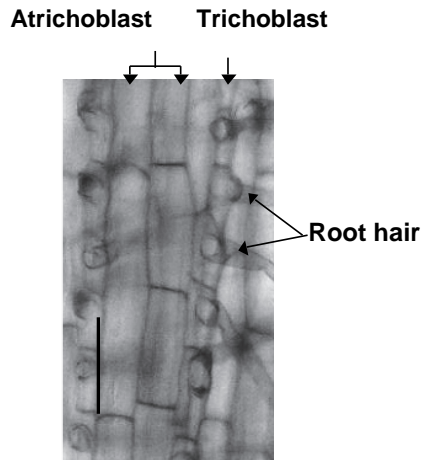

A
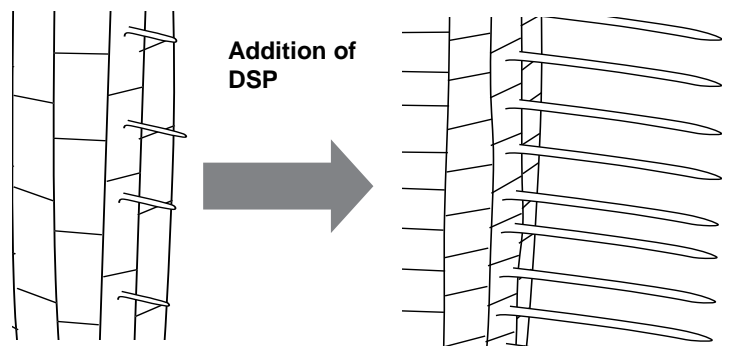

B

Fig. 7. Microscopic examination of root hairs grown in the presence of $30 \mu \mathrm{g} / \mathrm{ml}$ of degraded soybean meal products (DSP) (A) and a schematic model of the effect of DSP on trichoblast and atrichoblast (B). 


\subsection{Structure of exogenous peptide signal from DSP: analysis of protease from $B$. circulans HA12 for production of root hair promoting peptide(s)}

The protease from $B$. circulans HA12 was purified and characterized. The N-terminal amino acid sequence ( 20 amino acids) of the protease produced by $B$. circulans HA12 was identical to subtilisin Carlsberg, derived from B. licheniformis (Jacobs et al., 1985; Jacobs, 1995). The molecular weight of the protease was about $30 \mathrm{kDa}$. The protease was inhibited by phenylmethylsulfonyl fluoride and its optimum $\mathrm{pH}$ was around 10 . The protease from $B$. circulans HA12 was a subtilisin-like alkaline protease.

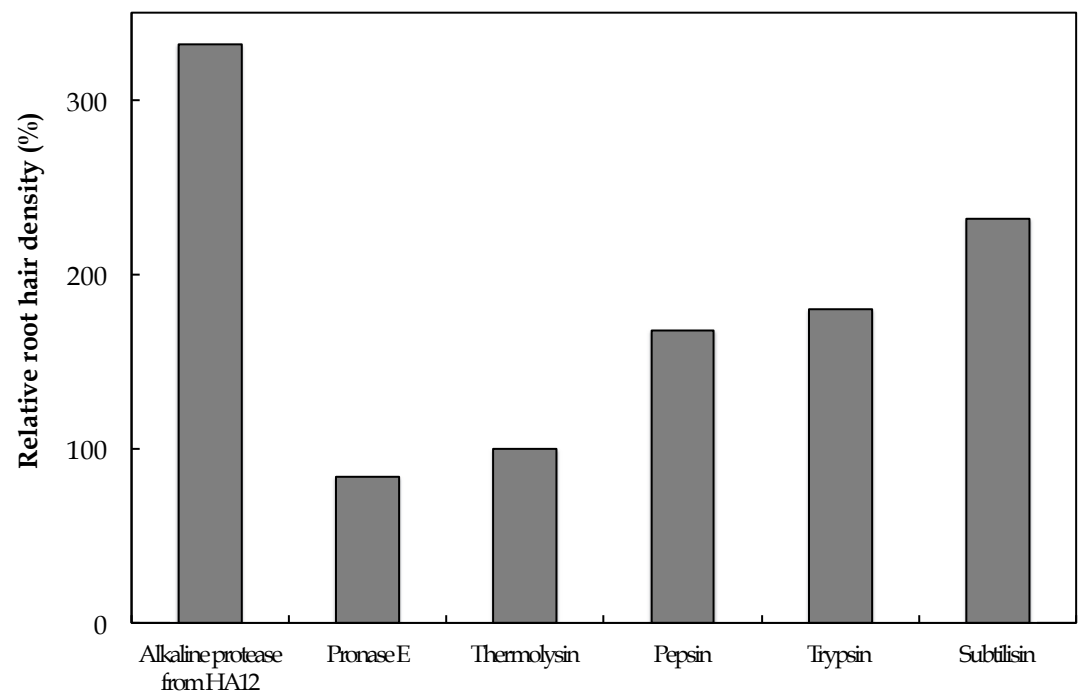

Fig. 8. Root hair promoting activity of various peptides.

Soybean meal was degraded by several proteases (pronase E, thermolysin, pepsin, trypsin, and subtilisin) and the root hair promoting activities of degraded products were analyzed. DSP by pronase $\mathrm{E}$ and thermolysin did not possess root hair promoting activity. Treatment by pepsin, trypsin, and subtilisin each showed root hair promoting activities, but these were lower than that of DSP (Fig. 8). The specific peptide(s) is produced by the degradation of soybean protein with an alkaline protease from B. circulans HA12.

\subsection{Structure of exogenous peptide signal from DSP: identification of the root hair promoting peptide}

Soybean contains various kinds of proteins, such as 7S globulin, 115 globulin, lectin and trypsin inhibitor (Brooks \& Morr, 1985; Hamblin \& Kent, 1973; Iibuchi \& Imahori, 1978a; Iibuchi \& Imahori, 1978b). The proteins were separated and purified by several steps, shown in Fig. 9. The separated soybean proteins were degraded by the alkaline protease from $B$. circulans HA12 and the root hair promoting activity of the degraded products from each fraction was analyzed (Table 7). Degraded products of Kunitz trypsin inhibitor (KTI), purified from whey protein, showed high root hair promoting activity, thus KTI was the origin protein for the root hair promoting peptide (Rackis et al., 1962).

The root hair promoting peptide from degraded products of KTI was purified by several chromatographic steps. The molecular mass was analyzed by matrix-assisted laser 


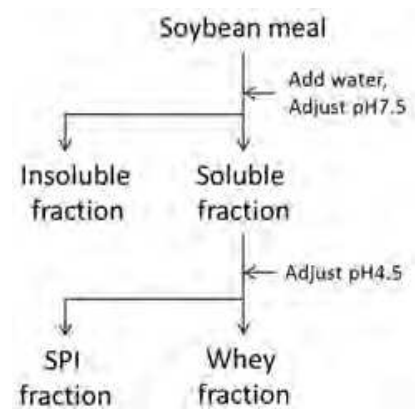

Fig. 9. Purification procedure of soybean meal proteins.

\begin{tabular}{lc}
\hline Treatment (peptides concentration) & Root hair promoting activity $(\%)$ \\
\hline Without addition of peptides and amino acids & 100.0 \\
DSP $(30 \mu \mathrm{g} / \mathrm{ml})$ & 331.1 \\
Degraded soluble protein fraction $(30 \mu \mathrm{g} / \mathrm{ml})$ & 337.1 \\
Whey protein fraction $(30 \mu \mathrm{g} / \mathrm{ml})$ & 335.5 \\
KTI $(10 \mu \mathrm{g} / \mathrm{ml})$ & 340.0 \\
\hline
\end{tabular}

Table 7. Root hair promoting activity of degraded products from each protein fraction. A

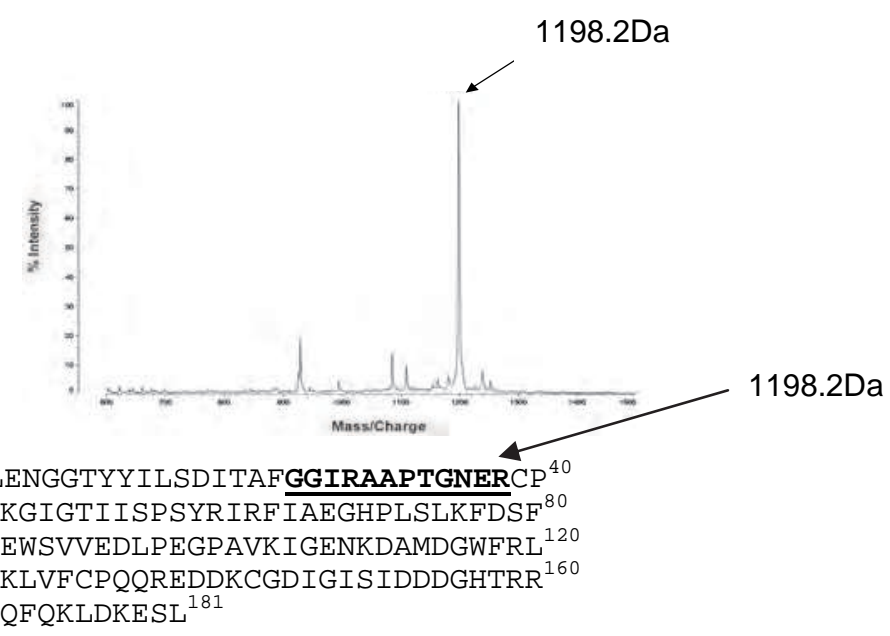

Fig. 10. Matrix-assisted laser desorption/ionization time-of-flight mass spectrometry spectra of root hair promoting peptide (A) and amino acid sequence of Kunitz trypsin inhibitor (B). The peptide sequence that is identical to $1198.2 \mathrm{Da}$ is underlined.

desorption/ionization time-of-flight mass spectrometry (MALDI-TOF MS). The molecular weight of the bioactive peptide was 1,198.2 Da (Fig. 10A), and the molecular weight of the amino acid sequences in KTI was searched. Positions 27 - 38 in KTI (Gly-Gly-Ile-Arg-AlaAla-Pro-Thr-Gly-Asn-Glu-Arg) were identical to the molecular weight, and the peptide was thus designated root hair promoting peptide (RHPP) (Fig. 10B). RHPP was chemically synthesized and also shown to have root hair promoting activity (Fig. 11). 


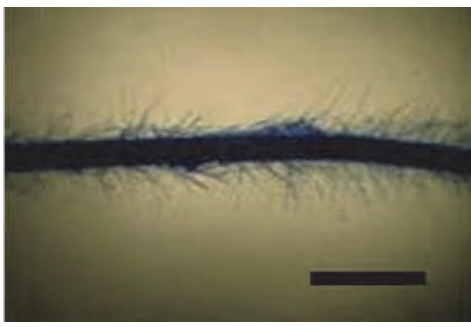

A

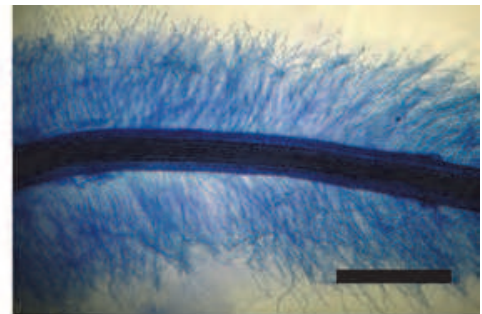

B

Fig. 11. Root hair promotion of chemically synthesized root hair promoting peptide (RHPP). A: plant growth medium, B: plant growth medium + chemically synthesized RHPP.

\subsection{Comparison of RHPP and other endogenous peptide signals}

RHPP consists of 12 amino acids and is rich in Ala, Arg, and Gly residues. The amino acid sequences of the endogenous peptide signals are shown in Table 8, and the length of each ranges from 5 to 96 . The amino acid sequences of exogenous peptide, RHPP, and endogenous peptides seem to have no relationship within their structure. The mechanisms of RHPP bioactivity (root hair promotion and adventitious root formation) seem to be different from those of endogenous peptide signals.

RHPP contains four residues of a-helix breaking amino acids and the root hair promoting activity was retained after heat treatment $\left(121^{\circ} \mathrm{C}, 15 \mathrm{~min}\right)$. Thus, secondary and tertiary structures of the peptide are not required for root hair promoting activity. On the other hand, the root hair promoting activity of RHPP decreased when one residue of the C terminus was deleted, indicating that the 12 residues of RHPP might be the minimum unit for expressing root hair promoting activity.

\begin{tabular}{|c|c|c|c|}
\hline Peptide & Role & Amino acid sequence & Reference \\
\hline CLV3 & $\begin{array}{l}\text { Proliferation of } \\
\text { cells in the apical } \\
\text { meristem }\end{array}$ & $\begin{array}{l}\text { MDSKSFVLLLLLFCFLFLHDASDLTQ } \\
\text { AHAHVQGLSNRKMMMMKMESEW } \\
\text { VGANGEAEKAKTKGLGLHEELRTVP } \\
\text { SGPDPLHHHVNPPRQPRNNFQLP }\end{array}$ & $\begin{array}{l}\text { (Kondo, et al. } \\
\text { 2006) }\end{array}$ \\
\hline Phytosulfokine & $\begin{array}{l}\text { Stimulate the } \\
\text { proliferation of } \\
\text { plant cells }\end{array}$ & $\mathrm{Y}\left(\mathrm{SO}_{3} \mathrm{H}\right) \mathrm{IY}\left(\mathrm{SO}_{3} \mathrm{H}\right) \mathrm{TQ}$ & $\begin{array}{l}\text { (Matsubayashi } \\
\text { et al., 1999) }\end{array}$ \\
\hline SCR/SP11 & $\begin{array}{l}\text { Self } \\
\text { incompatibility }\end{array}$ & $\begin{array}{l}\text { NLMKRCTRGFRKLGKCTTLEEEKCK } \\
\text { TLYPRGQCTCSDSKMNTHSCDCKSC }\end{array}$ & $\begin{array}{l}\text { (Suzuki et al., } \\
\text { 1999) }\end{array}$ \\
\hline Systemin & $\begin{array}{l}\text { Activates the } \\
\text { synthesis of } \\
\text { proteinase } \\
\text { inhibitors }\end{array}$ & AVQSKPPSKRDPPKMQTD & $\begin{array}{l}\text { (McGurl, et al., } \\
\text { 1992) }\end{array}$ \\
\hline RHPP & $\begin{array}{l}\text { Root hair } \\
\text { promotion } \\
\text { Adventitious } \\
\text { root formation }\end{array}$ & GGIRAAPTGNER & $\begin{array}{l}\text { (Matsumiya et } \\
\text { al., 2007) }\end{array}$ \\
\hline
\end{tabular}

Table 8. Characteristics of peptide signals for plants. 


\section{Analysis of peptide uptake in DSP and accumulation of RHPP in plant roots}

Inorganic nitrogen is one of the most important elements for plant growth. Plants usually absorb and utilize ammonia and nitrate as inorganic nitrogen for biosynthesis of proteins and nucleic acids. Lately, direct utilization of organic nitrogen, such as amino acids, peptides, and proteins, for plant growth has been found (Chapin et al., 1993; Kielland et al., 2006; Paungfoo-Lonhienne et al., 2008.). Growth of a rice plant in the presence of Gln was faster than that with nitrate.

On the other hand, L-methionine is known as a precursor of phytohormone. L-Met is absorbed into plant cells from root and stoma and converted to ethylene. Moreover, bioactivity of D-Met on roots has been also found (Hasegawa et al. 2002). DSP contains various kinds of peptides, and these seem to be utilized as nitrogen sources and/or bioactive compound(s). This section describes uptake of peptides in DSP and the accumulation of RHPP in plant roots.

\subsection{Uptake of peptides in DSP by $B$. rapa}

The peptide uptake was analyzed using B. rapa in the presence of DSP solution (Fig. 12). A decrease in peptide concentration was observed. B. rapa absorbed about $45 \%$ of the initial water volume, and the peptide concentration decreased by about $75 \%$, indicating that the plant seemed to positively absorb peptides in DSP.

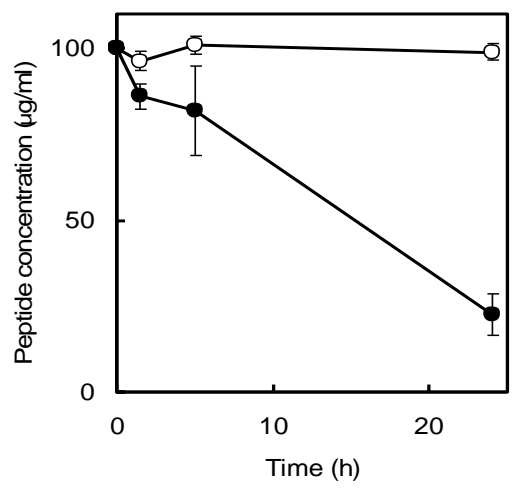

Fig. 12. Time course of peptides uptake from DSP solution by the root system of B. rapa. $\bigcirc$ : without plant (control), O: the root system of B. rapa was soaked in $100 \mu \mathrm{g} / \mathrm{ml}$ DSP solution.

Uptake of each peptide in DSP was analyzed by reversed phase HPLC (Fig. 13). All peaks decreased in intensity, suggesting that the plant absorbed many types of peptides (average uptake of peptides was $16.6 \%$ ). Three specific peaks were markedly absorbed in the plant (peaks a, b, and c decreased by 54.5, 30.9, and 33.2\%, respectively). Uptake of peptides by the plants seems to be influenced by the peptide lengths and amino acid sequences.

\subsection{Accumulation of fluorescence labeled RHPP in roots}

Carboxyfluorescein (FAM) labeled RHPP (FAM-RHPP) was synthesized for analysis of accumulation of RHPP. FAM-RHPP has root hair promoting activity at the same level as RHPP, so FAM-RHPP was used for further RHPP accumulation experiments. 
Accumulation of the peptide was analyzed using a confocal laser scanning microscope. Fluorescence was observed over the whole epidermal cell (trichoblast and atrichoblast) after soaking of the root system in a FAM-RHPP solution for 24 hour (Fig. 14). The peptide was accumulated in both trichoblasts and atrichoblasts, and subsequently, FAM-RHPP seemed to increase trichoblast and atrichoblast numbers.

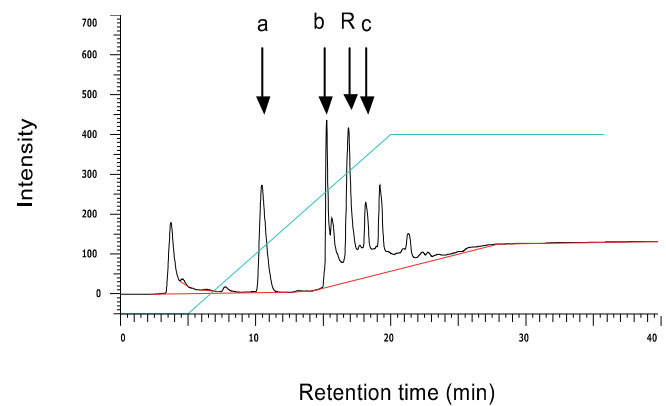

A

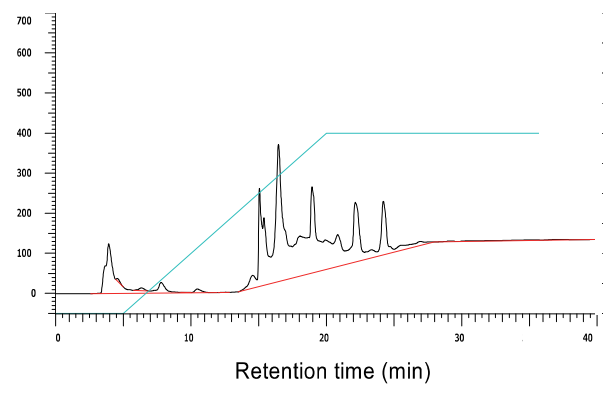

B

Fig. 13. Peptide uptake from degraded soybean meal products solution by the root system of Brassica rapa.

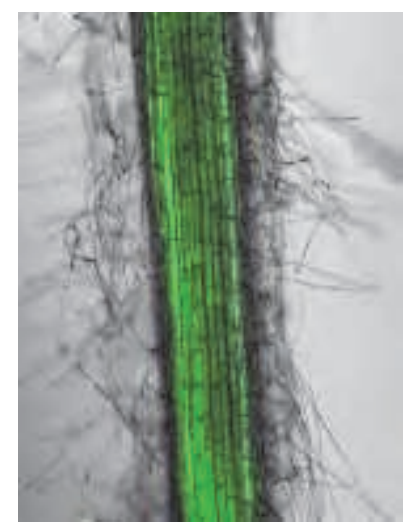

Fig. 14. Analysis of carboxyfluorescein-RHPP uptake in the root system of Brassica rapa by confocal laser scanning microscope.

\subsection{Hypothetical root hair promotion by RHPP}

Many kinds of peptides were generated by the degradation of soybean meal by the alkaline protease from $B$. circulans HA12. Several peptides in DSP are specifically absorbed into plants from the root system. RHPP seems to be absorbed into the root of $B$. rapa and accumulated in trichoblasts and atrichoblasts. RHPP in the cytoplasm of the root may affect the expression of specific gene(s) for the promotion of root hair numbers and root hair length. The surface area of the root system is increased by RHPP and consequently plant growth is stimulated by enhancement of nutrient uptake from the root system. 


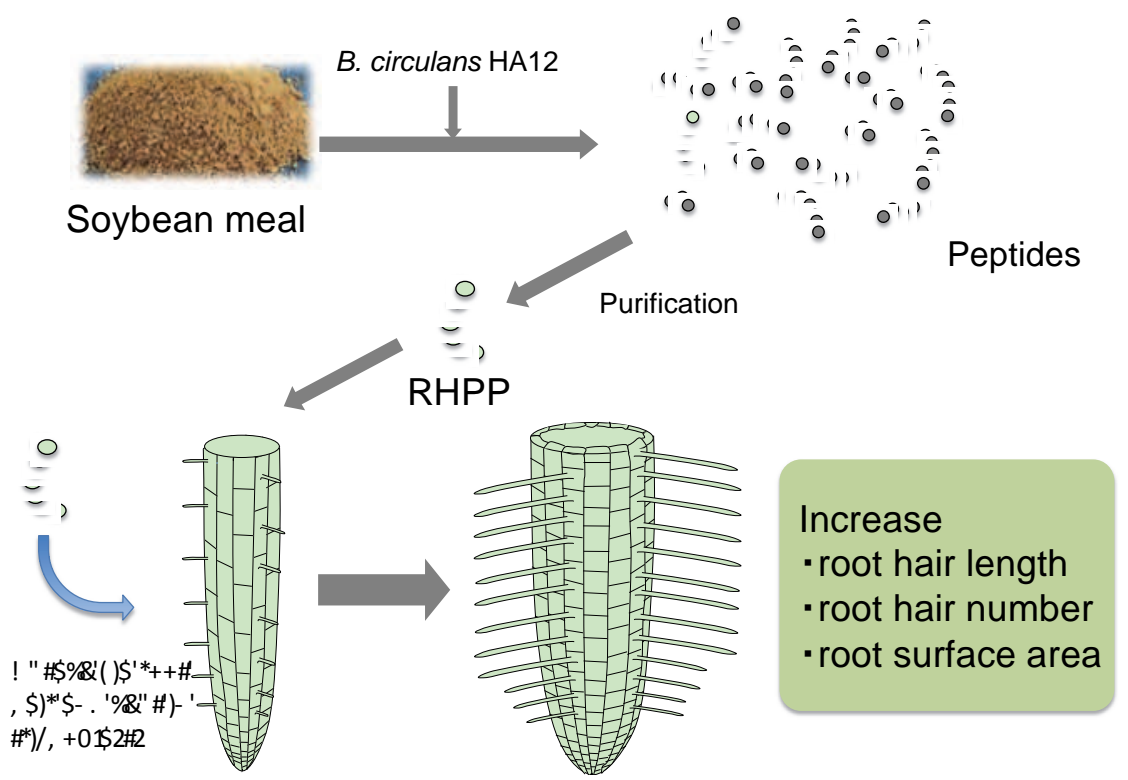

Fig. 15. Schematic model of internalization of the root hair promoting peptide.

\section{Conclusion}

This chapter describes utilization of soybean meal and the development of bioactive peptides for plant growth using soybean meal and the alkaline protease.

Section 1

A soybean meal degrading bacterium was isolated, identified, and designated as $B$. circulans HA12. The strain produced an alkaline protease. Soybean meal was degraded with $B$. circulans HA12, and DSP promoted various kinds of plant growth at low concentration. DSP increased root hair numbers for $B$. rapa and adventitious root was also formed from the stem of $L$. esculentum soaked in DSP solution. The bioactivity of DSP differs from that of phytohormones.

Section 2

DSP increased the number of epidermal cells without altering the localization patterns of trichoblasts and atrichoblasts. The root hair surface area was increased by about 16.6 times. The origin protein for RHPP was KTI, and RHPP was purified using KTI and the alkaline protease from $B$. circulans HA12. The structure of RHPP was analyzed by MALDI-TOF MS, and the amino acid sequence was identified (GGIRAAPTGNER; M.W. 1198.2 Da).

\section{Section 3}

Peptides in DSP were absorbed from the root system of B. rapa, but the uptake ratio was different for each peptide. RHPP was also absorbed into the plant and accumulated in both trichoblasts and atrichoblasts of the plant root. RHPP seemed to stimulate specific gene(s) that increase of number and length of root hair. 


\section{References}

Acea, M. J., Moore, C. R., \& Alexander, M. (1988). Survival and growth of bacteria introduced into soil. Soil Biology and Biochemistry, Vol. 20, No. 4, (December 2002), pp. 509-515, ISSN 0038-0717

Brooks, J. B. \& Morr, C. V. (1985). Current aspects of soy protein fractionation and nomenclature. Journal of the American Oil Chemists' Society, Vol. 62, No. 9, (September 1985), pp. 1347-1364, ISSN 0003-021X

Buchanan, R. E. \& Gibbons. N. E. (1974). Bergey's manual of determinative bacteriology, 8th ed. The Williams \& Wilkins Co., ISBN0683-41051-1, Baltimore, USA

Chapin, F. S., Moilanen, L., \& Kielland, K. (1993). Preferential use of organic nitrogen for growth by a non-mycorrhizal arctic sedge. Nature, Vol. 361, No. 6408, (January 1993), pp. 150-153, ISSN 0028-0836

Dolan, L. (1996). Pattern in the root epidermis: An interplay of diffusible signals and cellular geometry. Annals of Botany, Vol. 77, No. 6, (June 1996), pp. 547-553, ISSN 0305-7364

Farzamirad, V. \& Aluko, R. E. (2008) Angiotensin-converting enzyme inhibition and freeradical scavenging properties of cationic peptides derived from soybean protein hydrolysates. International Journal of Food Sciences and Nutrition. (August 2008), Vol. 59, No. 5, pp. 428-437, ISSN 0963-7486

Gaither, D. H. (1975). Auxin and the response of pea roots to auxin transport inhibitors: morphactin. Plant Physiology, Vol. 55, No. 6, (June 1975), pp. 1082-1086, ISSN 00320889

Gilroy, S. \& Jones, D. L. (2000). Though form to function: root hair development and nutrient uptake. Trends in Plant Science, Vol. 5, No. 2, (February 2000), pp. 56-60, ISSN 1360-1385

Hamblin, J. \& Kent, S. P. (1973). Possible role of phytohaemagglutinin in Phaseolus vulgaris L.. Nature New Biology, Vol. 245, No. 140, (September 1973), pp. 28-30, ISSN 00280836

Hasegawa, N., Fukumoto, Y., Minoda, M., Plikomol, A., \& Kubo, M. (2002). Promotion of plant and root growth by soybean meal degradation products. Biotechnology Letters, Vol. 24, No. 18, (September 2002), pp. 1483-1486, ISSN 1360-1385

Iibuchi, C. \& Imahori, K. (1978a). Heterogeneity and its relation to the subunit structure of the soybean 7S globulin. Agricultural and Biological Chemistry, Vol. 42, No. 1, (November 2008), pp. 31-36 ISSN 0002-1369

Iibuchi, C. \& Imahori, K. (1978b). Interconversion between monomer and dimmer of the 7S globulin of soybean seed. Agricultural and Biological Chemistry, Vol. 42, No. 1, (November 2008), pp. 25-30, ISSN 0002-1369

Ito, Y., Nakanomyo, I., Motose, H., Iwamoto, K., Sawa, S., Dohmae, N., \& Fukuda, H. (2006). Dodeca-CLE peptides as suppressors of plant stem cell differentiation. Science, Vol. 313, No. 5788, (August 2006), pp. 842-845, ISSN 0036-8075

Jacobs, M. F. (1995). Expression of the subtilisin Carlsberg-encoding gene in Bacillus licheniformis and Bacillus subtilis. Gene, Vol. 152, No. 1, (January 1995), pp. 69-74, ISSN 0378-1119

Jacobs, M., Eliasson, M., Uhlén, M., \& Flock, J. I. (1985). Cloning, sequencing and expression of subtilisin Carlsberg from Bacillus licheniformis. Nucleic Acids Research. Vol. 13, No. 24, (December 1985), pp. 8913-8926, ISSN 0305-1048

Kamimura, Y. \& Hayano, K. (2000). Properties of protease extracted from tea-field soil. Biology and Fertility of Soils, Vol. 30, No. 4, (January 2000), pp. 351-355, ISSN 01782762 
Kielland, K., McFarland, J., \& Olson, K. (2006). Amino acid uptake in deciduous and coniferous taiga ecosystems. Plant and Soil, Vol. 288, No. 1-2, (October 2006), pp. 297-307, ISSN 0032-079X

Klopper, J. W., Lifshitz, R., \& Zablotowicz, R. M. (1989). Free-living bacteria inocula for enhancing crop productivity. Trends in Biotechnology, Vol. 7, No. 2, (February 1989), pp. 39-44., ISSN 0167-7799

Kondo, T., Sawa, S., Kinoshita, A., Mizuno, S., Kakimoto, T., Fukuda, H., \& Sakagami, Y. (2006). A plant peptide encoded by CLV3 identified by in situ MALDI-TOF MS analysis. Science, Vol. 313, No. 5788, (August 2006), pp. 845-848, ISSN 0036-8075

Kubo, M., Okajima, J. \& Hasumi, F. (1994). Isolation and characterization of soybean wastedegrading microorganisms and analysis of fertilizes effect of degraded products. Applied and Environmental Microbiology, Vol. 60, No. 1, (January 1994), pp. 243-247, ISSN 0099-2240

Lauter, F. R., Ninnemann, O., Bucher, M., Riesmeier, J. W., \& Frommer, W. B. (1996). Preferential expression of an ammonium transporter and of two putative nitrate transporters in root hairs of tomato. Proceedings of the National Academy of Science of the United States of America, Vol. 93, No. 15, (July 1996), pp. 8139-8144, ISSN 10916490

Masucci, J. D. \& Schiefelbein, J. W. (1994). The rhd6 mutation of Arabidopsis thaliana alters root-hair initiation through an auxin- and ethylene-associated process. Plant Physiology, Vol. 106, No. 4, (December 1994), pp. 1335-1346, ISSN 0032-0889

Matsubayashi, Y. \& Sakagami, Y. (1996). Phytosulfokine, sulfated peptides that induce the proliferation of single mesophyll cells of Asparagus officinalis L. Proceedings of the National Academy of Science of the United States of America, Vol. 93, No. 15, (July 1996), pp. 7623-7627, ISSN 1091-6490

Matsubayashi, Y., Morita, A., Matsunaga, E., Furuya, A., Hanai, N., \& Sakagami, Y. (1999). Physiological relationships between auxin, cytokinin, and a peptide growth factor, phytosulfokine-a, in stimulation of asparagus cell proliferation. Planta, Vol. 207, No. 4, (February 1999), pp. 559-565, ISSN 0032-0935

Matsumiya, Y., Nishikawa, K., Aoshima, H., Inouye, K., \& Kubo, M. (2004). Analysis of autodegradation sites of thermolysin and enhancement of its thermostability by modifying Leu155 at an autodegradation site. Journal of Biochemistry, Vol. 135, No. 4, (April 2004), pp. 547-553, ISSN 0021-924X

Matsumiya, Y., Sumiyoshi, S., Matsukura, T., \& Kubo, M. (2007). Effect on epidermal cell of soybean protein-degraded products and structural determination of the root hair promoting peptide. Applied Microbiology and Biotechnology, Vol. 77, No. 1, (November 2007), pp. 37-43, ISSN 0175-7598

McGurl, B., Pearce, G., Orozco-Cardenas, M., \& Ryan, C. A. (1992) Structure, expression, and antisense inhibition of the systemin precursor gene. Science, Vol. 255, No. 5051, (March 1992), pp. 1570-1573, ISSN 0036-8075

O'Sullivan, M. P., Stephens, M., \& O'Gara, F. (1991). Extracellular protease production by fluorescent Pseudomonas spp and the colonization of sugarbeet roots and soil. Soil Biology and Biochemistry, Vol. 23, No. 7, (1991), pp. 623-627, ISSN 0038-0717

Okuda, A. (1961). Dojou hiryou sousetu, Yokendou, Co. LTD., Tokyo, Japan

Paungfoo-Lonhienne, C., Lonhienne, T. G., Rentsch, D., Robinson, N., Christie, M., Webb, R. I., Gamage, H. K., Carroll, B. J., Schenk, P. M., \& Schmidt, S. (2008). Plants can use protein as a nitrogen source without assistance from other organisms. Proceedings of the National Academy of Science of the United States of America, Vol. 105, No. 11, (March 2008), pp. 4524-4529, ISSN 1091-6490 
Pearce, G., Strydom, D., Jonson, S., \& Ryan, C. A. (1991). A Polypeptide from tomato leaves induces wound-inducible proteinase inhibitor proteins. Science, Vol. 253, No. 5022, (August 1991), pp. 895-898, ISSN 0036-8075

Pitts, R. J., Cernac, A., \& Estelle, M. (1998). Auxin and ethylene promote root hair elongation in Arabidopsis. The Plant Journal, Vol. 16, No. 5, (December 1998), pp. 553-560, ISSN 0960-7412

Rackis, J. J., Sasame, H. A., Mann, R. K., Anderson, R. L., \& Smith, A. K. (1962). Soybean trypsin inhibitors: isolation, purification and physical properties. Archives of Biochemistry and Biophysics, Vol. 98, No. 3, (September 1962), pp. 471-478, ISSN 00039861

Ryu, C. M., Farag, M. A., Hu, C. H., Reddy, M. S., Wei, H. X., Pare, P. W., \& Kloepper, J. W. (2003). Bacterial volatiles promote growth in Arabidopsis. Proceedings of the National Academy of Science of the United States of America, Vol. 100, No. 8, (April 2003), pp. 4927-4932, ISSN 1091-6490

Schopfer, C. R., Nasrallah, M. E., \& Nasrallah, J. B. (1999). The male determinant of selfincompatibility in Brassica. Science, Vol. 286, No. 5445, (November 1999), pp. 16971700, ISSN 0036-8075

Shinano, T., Osaki, M., \& Tadano, T. (1991). Effects of nitrogen application on reconstruction of nitrogen compounds during the maturation stage in several field crops. Soil Science and Plant Nutrition, Vol. 37, No. 2, (June 1991), pp. 259-270, ISSN 0038-0768

Smith, S. J., Young, L. B., \& Miller, G. E. (1977). Evaluation of soil nitrogen mineralization potentials under modified field conditions. Soil Science Society of America Journal, Vol. 41, (January-February 1977), pp. 74-76, ISSN 0361-5995

Suzuki, G., Kai, N., Hirose, T., Fukui, K., Nishio, T., Takayama, S., Isogai, A., Watanabe, M., \& Hinata, K. (1999). Genomic organization of the S locus: Identification and characterization of genes in SLG/SRK region of $\mathrm{S}^{9}$ haplotype of Brassica campestris (syn. rapa). Genetics, Vol. 153, No. 1, (September 1999), pp. 391-400, ISSN 0016-6731

Tanimoto, M., Roberts, K., \& Dolan, L. (1995). Ethylene is a positive regulator of root hair development in Arabidopsis thaliana. The Plant Journal, Vol. 8, No. 6, (December 1995), pp. 943-948, ISSN 0960-7412

Uchida, M. (2007). Prospects for World Trade in the Soybean Sector. Journal of Nagoya Bunri University, Vol. 7, (March 2007), pp. 97-102, ISSN 1346-1982

Watanabe, K. \& Hayano, K. (1995). Seasonal variation of soil protease activities and their relation to proteolytic bacteria and Bacillus spp in paddy field soil. Soil Biology and Biochemistry, Vol. 27, No. 2, (February 1995), pp. 197-203, ISSN 0038-0717

Yamazaki, H. \& Roppingi, K. (1998). The effect of organic matters application for leaf vegetable yield and quality. Saitamaen Shikenhou, Vol. 21, (March 1998), pp. 7-20, ISSN 0385-3675

Yonekura, M. \& Tanaka, A. (2003). Isolation and application of physiologically active peptides from soybean whey and okara proteins. Soy Protein Research, Japan, Vol. 6, No. 24, (2003), pp. 88-93, ISSN 1344-4050

Yonekura, M. \& Yamamoto, A. (2004). Isolation and application of physiologically active peptides from soybean whey and okara proteins. Soy Protein Research, Japan, Vol. 7, No. 25, (2004), pp. 79-84, ISSN 1344-4050 


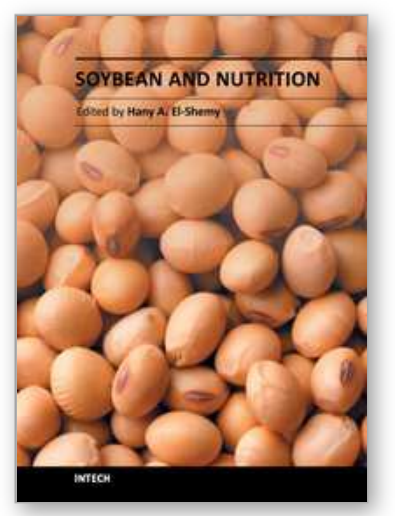

\author{
Soybean and Nutrition \\ Edited by Prof. Hany El-Shemy
}

ISBN 978-953-307-536-5

Hard cover, 476 pages

Publisher InTech

Published online 12, September, 2011

Published in print edition September, 2011

Worldwide, soybean seed proteins represent a major source of amino acids for human and animal nutrition. Soybean seeds are an important and economical source of protein in the diet of many developed and developing countries. Soy is a complete protein and soy-foods are rich in vitamins and minerals. Soybean protein provides all the essential amino acids in the amounts needed for human health. Recent research suggests that soy may also lower risk of prostate, colon and breast cancers as well as osteoporosis and other bone health problems and alleviate hot flashes associated with menopause. This volume is expected to be useful for student, researchers and public who are interested in soybean.

\title{
How to reference
}

In order to correctly reference this scholarly work, feel free to copy and paste the following:

Yoshiki Matsumiya and Motoki Kubo (2011). Soybean Peptide: Novel Plant Growth Promoting Peptide from Soybean, Soybean and Nutrition, Prof. Hany El-Shemy (Ed.), ISBN: 978-953-307-536-5, InTech, Available from: http://www.intechopen.com/books/soybean-and-nutrition/soybean-peptide-novel-plant-growth-promotingpeptide-from-soybean

\section{INTECH}

open science | open minds

\section{InTech Europe}

University Campus STeP Ri Slavka Krautzeka 83/A 51000 Rijeka, Croatia Phone: +385 (51) 770447

Fax: +385 (51) 686166 www.intechopen.com

\section{InTech China}

Unit 405, Office Block, Hotel Equatorial Shanghai No.65, Yan An Road (West), Shanghai, 200040, China 中国上海市延安西路65号上海国际贵都大饭店办公楼405单元 Phone: $+86-21-62489820$

Fax: $+86-21-62489821$ 
(C) 2011 The Author(s). Licensee IntechOpen. This chapter is distributed under the terms of the Creative Commons Attribution-NonCommercialShareAlike-3.0 License, which permits use, distribution and reproduction for non-commercial purposes, provided the original is properly cited and derivative works building on this content are distributed under the same license. 